\title{
Pengembangan Sumber Daya Manusia dalam Meningkatkan Kualitas Pendidikan di SD Negeri Inpres Angkasa Biak
}

\author{
Krismiyati \\ Institut Ilmu Sosial dan Ilmu Politik Yapis Biak
}

\begin{abstract}
ABSTRAK
Penelitian ini tujuan untuk mengetahui pengembangan sumber daya manusia di SD Negeri Inpres Angkasa Biak. Adapun lokasi penelitian dilakukan di Inpres Angkasa Biak. Metode penelitian ini adalah kualitatif yang mengembangkan konsep dan mengumpulkan fakta, namun tidak menguji hipotesis melalui angka. Untuk mengumpulkan data, reseacher mewawancarai para guru. Wawancara berdasarkan tiga indikator yaitu kepribadian, keterampilan dan pelatihan. Hasil penelitian ini bahwa upaya pengembangan sumber daya manusia berjalan dengan baik namun pelatihannya belum maksimal dilakukan.
\end{abstract}

Kata kunci: Sumber Daya Manusia, Guru

\begin{abstract}
This study aims to find out the development of human resources in Elementary School Inpres Angkasa Biak. The location of research conducted in Inpres Angkasa Biak. This research method is qualitative that develops concepts and collects facts, but does not test hypotheses through numbers. To collect data, the reseacher interviewed the teachers. Interview based on three indicators: personality, skills and training. The result of this research is that human resources development effort is running well but the training has not been maximally done.
\end{abstract}

Keywords: Human Resources, Master

\section{PENDAHULUAN}

Pada saat ini masyarakat Indonesia tengah memasuki era globalisasi dan moderenisasi yang penuh dengan tantangan yang menuntut masyarakat Indonesia menjadi manusia yang lebih berkualitas tinggi dengan wawasan luas dan segala ketrampilan yang dimiliki. Seiring dengan kemajuan dalam bidang ilmu pengetahuan dan teknologi, maka setiap organisasi harus mampu menerapkan, memanfaatkan, serta mengelolanya.Berhubungan dengan perkembangan tersebut, maka pelaksanaan berbagai usaha yang dilakukan organisasi maupun lembaga harus sejalan dengan kemajuan dan perkembangan yang ada. Dengan begitu tugas pekerjaan yang diemban semakin berat dan membutuhkan spesifikasi kemampuan dan keterampilan yang spesifik pula, untuk menjamin tiap bidang pekerjaan terlaksana sesuai dengan tujuan yang telah direncanakan.

Proses pencapaian tujuan tersebut perlu adanya usaha yang dapat membantu meningkatkan kemampuan dan keterampilan tersebut. Salah satu usaha yang dapat dilakukan organisasi atau lembaga yaitu pengembangan sumber daya manusia. Pengembangan sumber 
daya manusia berkaitan dengan tersedianya kesempatan dan pengembangan belajar, membuat program-program training yang meliputi perencanaan, penyelenggaraan, dan evaluasi atas program-program tersebut.Pengembangan sumber daya manusia dapat didefinisikan sebagai seperangkat aktivitas yang sistematis dan terencana yang dirancang dalam memfasilitasi para pegawainya dengan kecakapan yang dibutuhkan untuk memenuhi tuntutan pekerjaan, baik pada saat ini maupun masa yang akan datang. Serta suatu usaha yang terencana dan berkelanjutan yang dilakukan oleh organisasi dalam meningkatkan kompetensi pegawai dan kinerja organisasi melalui program-program pelatihan, pendidikan, dan pengembangan. Yang perlu dilakukan secara terencana dan berkesinambungan agar pengembangan dapat dilaksanakan dengan baik.Potensi manusia yang nantinya ditunjukkan dalam aspek yang salah satunya adalah kualitas, hanya dapat dicapai dengan adanya pengembangan sumber daya manusia. Hal tersebut diperlukan karena sumber daya manusia merupakan faktor yang paling mempengaruhi kehidupan. Kemampuan manusia untuk mempengaruhi alamnya menunjukkan bahwa posisi sumber daya manusia sangat sentral adanya.

Segala aktivitas yang dilakukan oleh organisasi atau instansi dalam memfasilitasi pegawai agar memiliki pengetahuan, keahlian, dan/ atau sikap yang dibutuhkan dalam menangani pekerjaan saat ini atau yang akan datang. Aktivitas yang dimaksud, tidak hanya pada aspek pendidikan dan pelatihan saja, akan tetapi menyangkut aspek karier dan pengembangan organisasi. Dengan kata lain, pengembangan sumber daya manusia berkaitan erat dengan upaya meningkatkan pengetahuan, kemampuan, dan/ atau sikap anggota organisasi serta penyediaan jalur karier yang didukung oleh fleksibilitas organisasi dalam mencapai tujuan organisasi. Setiap sumber daya manusia yang ada di dalam suatu porganisasi atau lembaga (instansi) dituntut agar bekerja efektif, efisien kualitas dan kuantitas pekerjaannya baik sehingga daya saing perusahaan semakin besar. Pengembangan ini dilakukan untuk tujuan nonkarier maupun karier bagi sumber daya manusia melalui latihan dan pendidikan. Suatu negara dan bangsa akan maju apabila rakyatnya memiliki pendidikan yang tinggi dan berkualitas, sebaliknya suatu negara akan tertinggal dari negara dan bangsa lain apabila pendidikan rakyatnya rendah dan tidak berkualitas. Tanpa sumber daya manusia yang berkualitas, suatu bangsa akan tertinggal dari bangsa lain dalam percaturan dan persaingan kehidupan global yang semakin kompetitif. Pendidikan yang baik pada hakekatnya adalah pendidikan yang berkualitas. Pendidikan harus memenuhi standar, metode dan kurikulum yang tepat, serta kualitas guru yang baik ((Yudhoyono, 2007).

Dalam pembelajaran yang harus diperhatikan adalah proses, bukan semata-mata hasil akhir (Nurgiyantoro, 2010). Dengan kondisi tenaga pendidik yang diposisikan sebagai sentral keterlaksanaan proses pembelajaran di sekolah, maka senantiasa menjadi topik pembicaraan dan sorotan banyak pihak berkaitan dengan kinerjanya. Kesenjangan yang terjadi dari fenomena tersebut, diharapkan pada masa yang akan datang setiap sekolah harus didukung oleh para guru yang kompeten dan memiliki jiwa kader yang senantiasa bergairah dalam melaksanakan tugas profesionalnya secara inovatif untuk mencapai pendidikan bangsa yang lebih berkualitas.Meningkatkan kualitas pendidikan di Indonesia, bukan hanya menjadi tanggung jawab pemerintah, tetapi juga merupakan tanggung jawab semua lapisan masyarakat. Hal ini berlaku juga dengan pengembangan SDM yaitu tenaga pendidik yang memegang peranan utama dalam penyelenggaraan pembelajaran di sekolah dan bagian yang tidak bisa terpisahkan dari 
sebuah bangsa, bahkan maju atau mundurnya kualitas suatu bangsa dapat diukur melalui maju atau tidaknya dalam sektor pendidikan. Jika ingin memajukan sebuah bangsa maka hal pertama yang harus dilakukan adalah dengan meningkatkan kualitas pendidikan yang ada.

Mutu pendidikan sering diartikan sebagai karakteristik jasa pendidikan yang sesuai dengan kriteria tertentu untuk memenuhi kepuasan pengguna pendidikan, yakni peserta didik, orang tua, serta pihak-pihak berkepentingan lainnya. Dalam menjaga mutu proses tersebut, diperlukan adanya quality controll yang mengawasi jalannya proses dan segala komponen pendukungnya. Kualitas pendidikan memiliki arti bahwa lulusan pendidikan memiliki kemampuan yang sesuai sehingga dapat memberikan kontribusi yang tinggi bagi pembangunan, terutama ditentukan oleh proses belajar mengajar tersebut tenaga pendidik memegang peran yang penting. Tenaga pendidik adalah kreator proses belajar mengajar. Ia adalah orang yang akan mengembangkan suasana bebas bagi siswa untuk mengkaji apa yang menarik dan mampu mengekspresikan ide-ide dan kretivitasnya dalam batas-batas norma-norma yang ditegakkan secara konsisten.

Tenaga pendidik (guru) merupakan elemen kunci dalam sistem pendidikan, khususnya di sekolah (Departemen Pendidikan Nasional, 2008). Hal ini disebabkan karena guru merupakan titik sentral dalam pembaharuan dan peningkatan mutu pendidikan, dengan kata lain salah satu persyaratan penting bagi terwujudnya pendidikan yang bermutu adalah apabila pelaksanaannya dilakukan oleh pendidik-pendidik yang keprofesionalannya dapat diandalkan. Tinggi rendahnya mutu hasil belajar siswa banyak tergantung pada kemampuan mengajar guru. Apabila guru memiliki kemampuan mengajar yang baik, maka akan membawa dampak peningkatan iklim belajar mengajar yang baik.

Undang-undang Republik Indonesia nomor 20 tahun 2003 tentang sistem pendidikan nasional menyatakan bahwa "jenjang pendidikan dasar dan menengah adalah jenis pendidikan formal untuk peserta didik usia 7 sampai 18 tahun dan merupakan persyaratan dasar bagi pendidikan yang lebih tinggi”. Jika usia anak pada saat masuk sekolah dasar, merujuk pada definisi pendidikan dasar dalam Undang-Undang tersebut, berarti pengertian sekolah dasar dapat dikatakan sebagai institusi pendidikan yang menyelenggarakan proses pendidikan dasar selama masa enam tahun yang ditujukan bagi anak usia 7-12 tahun. Pendidikan dapat berlangsung di sekolah sebagai institusi pendidikan formal, yang diselenggarakan melalui proses belajar mengajar. Suhartono (2008) menyatakan bahwa "menurut pendekatan dari sudut pandang sempit, pendidikan merupakan seluruh kegiatan yang direncanakan serta dilaksanakan secara teratur dan terarah di lembaga pendidikan sekolah". Oktama (2013) menyatakan bahwa "sekolah dasar pada dasarnya merupakan lembaga pendidikan yang mnyelenggarakan program pendidikan enam tahun bagi anak-anak usia 6-12 tahun." Hal senada juga diungkapkan Widoyoko (2009) bahwa "sekolah dasar sebagai satu kesatuan dilaksanakan dalam masa program belajar selama 6 tahun." Mencermati kedua pernyataan Suharjo dan Fuad Ihsan dapat dijelaskan bahwa sekolah dasar merupakan jenjang pendidikan yang berlangsung selama enam tahun.

Sekolah adalah suatu lembaga atau tempat untuk belajar seperti membaca, menulis dan belajar untuk berperilaku yang baik. Sekolah juga merupakan bagian integral dari suatu masyarakat yang berhadapan dengan kondisi nyata yang terdapat dalam masyarakat pada masa sekarang. Sekolah juga merupakan lingkungan kedua tempat anak-anak berlatih dan 
46| Jurnal Office, Vol.3, No.1, 2017

menumbuhkan kepribadiannya. Selain itu proses pendidikan di sekolah juga tidak terpisahkan dengan lingkungan keluarga maupun pergaulan peserta didik (Arbi \& Syahrun, 1993). SDN Inpres Angkasa merupakan salah satu sekolah dasar negeri yang berada di Kabupaten Biak Numfor. Dengan segala sarana dan prasarana yang disediakan tentunya sangat menunjang kualitas pendidikan yang diberikan kepada peserta didik. Pada setiap kelas terdapat satu guru kelas yang siap menyampaikan pembelajaran. Pembelajaran yang berkualitas sangat bergantung pada usaha SDM dalam mengelola dan mengontrol kelas dengan maksimal.

Dalam hal ini keberhasilan pendidikan tidak terlepas dari beberapa faktor pendukung. Faktor pendukung tersebut adalah pendidik, yang dididik, materi pembelajaran, metode pembelajaran, tujuan dan faktor yang terakhir adalah faktor lingkungan. Beberapa faktor tersebut merupakan penyukses pendidikan yang terbungkus dalam sebuah lembaga pendidikan yang disebut dengan sekolah. Sekolah merupakan wadah penyalur pendidikan kepada peserta didik oleh pendidik yang dianggap mampu dalam menyalurkan segala pengetahuan.Dari hasil pengamatan awal di Sekolah Dasar Negeri Inpres Angkasa Biak diperoleh gambaran bahwa Sumber Daya Manusia pada Sekolah Dasar tersebut belum optimal, dikarenakan masing masing ruang kelas memiliki tenaga pendidik yang berbeda kemampuan dan keterampilan dalam mengajar, dan karakter yang berbeda. Contohnya kelas satu sampai kelas empat yang memiliki dua kelas berbeda yaitu kelas A dan kelas B, yang akibatnya diantara kelas yang berbeda tersebut akan memiliki cara pengajaran yang tidak sama. Walaupun dengan kurikulum yang dipakai sama dalam penerapan pembelajaran di dua kelas berbeda tersebut, dengan karakter tenaga pendidik yang berbeda akan menimbulkan suatu perbedaan akan pemahaman materi antara kelas A dan kelas B. Dengan demikian, disini perlu penyamaan suatu konsep dan persepsi pembelajaran yang saling berhubungan antara tenaga pendidik. Maka, di sinilah peran pengembangan sumber daya yang dimaksud sangat diperlukan bagi para tenaga pendidik pada SD tersebut agar memiliki pandangan yang sama untuk meningkatkan mutu pendidikan yang berlangsung.

\section{METODE PENELITIAN}

Lokasi penelitian yang dilakukan bertempat di Sekolah Dasar Negeri Inpres Angkasa Kabupaten Biak Numfor yang beralamat di Jalan DS Yan Mamoribo Biak.Metode yang digunakan dalam penelitian ini adalah metode penelitian kualitatif. Pada penelitian ini, mengembangkan konsep dan menghimpun fakta, tetapi tidak melakukan pengujian hipotesis melalui perhitungan angka-angka. Dalam penelitian ini, jenis dan sumber data yang digunakan ialah data primer maupun data skunder yang didapatkan dianalisis dengan model analisis data Spradley yaitu meliputi analsis domain, analsisis Taksonomi, analisis komponensial dan analisis Tema. 


\section{HASIL PENELITIAN PEMBAHASAN}

Pengembangan sumber daya manusia, peneliti menggunakan teori dari Latham, Wexley, \& Pursell (1975) mengatakan bahwa program pelatihan dan pengembangan memiliki satu atau lebih tujuan - tujuan berikut ini pertama meningkatkan kesadaran diri individu, kedua meningkatkan keterampilan individu dalam satu bidang keahlian atau lebih dan ketiga meningkatkan motivasi individu untuk melaksanakan tugas atau pekerjaannya secara memuaskan. Dari teori tersebut peneliti menyimpulkan 3 (tiga) indikator pengembangan sumber daya manusia, seperti: 1) motivasi, 2) kepribadian dan 3) keterampilan.

\section{Motivasi}

Motivasi adalah dorongan hati atau jiwa yang menjadi dasar atau alasan untuk melakukan sesuatu kegiatan pekerjaan. Dalam pengkajian ini motivasi diukur dengan menggunakan konsep yang dikembangkan oleh Mc Clelland. Menurut Mc Clelland ada tiga hal yang mendorong seseorang untuk melakukan sesuatu yaitu: motivasi terhadap prestasi (dorongan hati untuk memberikan sumbangan/kontribusi nyata dalam setiap kegiatan), motivasi terhadap kekuasaan (dorongan hati untuk mempengaruhi perilaku orang lain serta mengontrol dan memanipulasi lingkungan), dan motivasi berafiliasi (dorongan hati untuk berhubungan dengan orang lain serta untuk disenangi orang lain) (Puspitarini \& Kusumawati, 2011).

Berdasarkan pengertian Mc Clelland peneliti menyimpulkan, bahwa motivasi ialah suatu dorongan atau penyemangat kepada seseorang agar orang tersebut dapat berusaha untuk melakukan apa yang diingikan itu tercapai dengan baik. Berikut Kesimpulan hasil wawancara yang telah dilakukan oleh peneliti pada Ibu Sujiati, A.Ma (PLH Kepala Sekolah), wali kelas IA Ibu Adolfin P, A. Ma. Pd, wali kelas IB Ibu Evelina Taruk, wali kelas IIIA Ibu J. Handayani, wali kelas IIIB Ibu Riska Ageng Kristanti yaitu motivasi Motivasi tenaga pendidik adalah guru harus selalu belajar, memberikan dorongan ke anak murid suapaya rajin dan giat belajar dan motivasi yang harus dimiliki seorang guru dalam mendidik, adalah mencerdaskan anak didik serta membentuk moral dan mental anak didik tersebut.

\section{Kepribadian}

Kepribadian mencakup kebiasaan, sikap, sifat, yang dimiliki seseorang yang berkembang ketika seseorang berhubungan dengan orang lain. Kepribadian sangat kaitannya dengan nilai dan norma, dan perilaku. Kepribadian merupakan konsep luas yang, sehingga pengertian kepribadian banyak ditanggapi berbeda-beda oleh para ahli Sosiologi. Namun dari definisi pengertian kepribadian saling melengkapi dan memperkata konsep kepribadian. Menurut John F. Cuber, kepribadian adalah keseluruhan sifat yang tampak dan dapat dilihat oleh seseorang. Aspek-aspek peribadian menurut (Syamsuddin Makmun, 2003) yang mengemukakan mengenai aspek-apek kerpibadian yaitu sebagai berikut:

a. Karakter, adalah konsekuen tidaknya mematuhi etika perilaku konsiten tidaknya dalam memegang pendirian atau pendapat. 
b. Temperamen, adalah disposisi rekatif seorang, atau cepat lambatnya mengenai mereaksi terhadap rangsangan-rangsangan akan yang datang dari lingkungannya.

c. Sikap, ialah sambutan terhadap objek yang sifatnya positif, negatif atau ambivalen.

d. Stabilitas emosi, yaitu ukuran kestabilan reaksi emosional terhadap rangsangan lingkungannya, Misalnya mudah tidak tersinggung, marah, putus asah atau sedih.

e. Responsibilitas (tanggung jawab), yaitu kesiapan untuk menerima risiko dari tindakan atau perbuatan yang dilakukan. Misalnya mau menerima risiko yang wajar, cuci tangan, atau melarikan diri dari risiko yang dihadapi.

f. Sosiabilitas, adalah disposisi pribadi yang berkaitan dengan hubungan interpersonal. Misalnya, sifat pribadi yang terbuka atau tertutup dan kemampuan berkomunikasi dengan orang lain.

Berikut hasil kesimpulan wawancara tentang kepribadian tenaga pendidik atau guru yang dilakukan pada Ibu Sujiati, A.Ma (PLH Kepala Sekolah), wali kelas IA Ibu Adolfin P, A. Ma. Pd, wali kelas IB Ibu Evelina Taruk, wali kelas IIIA Ibu J. Handayani, wali kelas IIIB Ibu Riska Ageng Kristanti Yaitu Kepribadian yang seharusnya dimiliki oleh seorang pendidik itu adalah harus loyal kepada atasan atau pimpinan, mematuhi tata tertib yang berlaku di sekolah, yang sabar dan bisa menjadi panutan siswa, dan juga di lingkungan mereka berada.Kepribadian sebagai tenaga pendidik, memiliki kepribadian yang bisa menjadi panutan anak didik baik semua ucapan, perbuatan, kesopanan, dan penampilan. Seperti semboyan Ki Hajar Dewantara, Ing ngarso sun tulodo, Ing madyo mangun karso dan Tut wuri handayani. Alasannya, seorang pendidik sebagai pembelajar yang menjadi panutan makanya harus memiliki karakter yang baik dan harus bisa jadi contoh, memberi semangat dan dorongan.

\section{Keterampilan}

Menurut Ariani (2013) terampil adalah cakap dalam menyelesaikan tugas, mampu dan cekatan. Keterampilan adalah kecakapan untuk menyelesaikan tugas. atau kecakapan yang disyaratkan. Dalam pengertian luas, jelas bahwa setiap cara yang digunakan untuk mengembangkan manusia, bermutu dan memiliki pengetahuan, keterampilan dan kemampuan sebagaimana diisyaratkan (Suparno, 2001). Berdasarkan pengertian tersebut, setiap tenaga pendidik atau guru harus memiliki keterampilan yang baik sesuai karakter masing - masing. Maka, dari pengertian di atas peneliti melakukan wawancara seputar ketermpilan. Berikut kesimpulan wawancara yang dilakukan kepada sejumlah narasumber yaitu Ibu Sujiati, A.Ma (PLH Kepala Sekolah), wali kelas IA Ibu Adolfin P, A. Ma. Pd, wali kelas IB Ibu Evelina Taruk, wali kelas IIIA Ibu J. Handayani, wali kelas IIIB Ibu Riska Ageng Kristanti.Guru harus terampil dalam segala aspek sesuai dengan tupoksinya, agar murid - muridnya menjadi anak yang bermoral, pandai dan sukses dalam masa depannya.Keterampilan yang harus dimiliki,bisa menerangkan materi kepada anak murid supaya bisa dipahami contohnya terampil dalam berbicara dan menyampaikan materi. Keterampilan yang harus dimiliki tenaga pendidik, keterampilam mengajar dan aspek - aspek lain yang menunjang profesi dan perkembangan zaman.

Hasil wawancara yang peneliti lakukan, maka dapat disimpulkan bahwa ketiga indikator tersebut sangat berpengaruh pada penigkatan mutu pendidikan. Maka, tenaga pendidik/ guru 
pada SDN Inpres Angkasa Biak sangat mendukung adanya pengembangan sumber daya manusia ataupun pelatihan dalam mengikuti perkembangan zaman yang terus maju. Indikator dalam pengembangan sumber daya manusia atau tenaga pendidik yang telah dijelaskan tersebut, maka berikut ini peneliti menyajikan kesimpulan hasil wawancara seputar Pengembangan Sumber Daya Manuisa atau Tenaga Pendidik. Wawancara di lakukan pada Ibu Sujiati, A.Ma (PLH Kepala Sekolah), wali kelas IA Ibu Adolfin P, A. Ma. Pd, wali kelas IB Ibu Evelina Taruk, wali kelas IIIA Ibu J. Handayani, wali kelas IIIB Ibu Riska Ageng Kristanti, Sangat perlu pelatihan atau pengembangan SDM dilakukan, alasannya dengan semakin lajunya perkembangan teknologi, seorang guru dituntut untuk mengikuti perkembangan di era modern ini.Perlu, seluruh tenaga pendidk mengikuti pelatihan alasannya agar guru semakin profesional dalam mengemban tugas - tugasnya. Sekolah mengadakan pelatihan komputer, kegiatan kelompok kerja guru atau KKG dan workshop. Perlu dilakukannya pelatihan,untuk meningkatkan kemampuan guru dalam perkembangan zaman, kita dituntut untuk memiliki pengetahuan sesuai zamannya. Pelatihan berfungsi untuk menyegarkan atau penyegaran ilmu ilmu dan pengetahuan yang dimiliki atau menambah pengetahuan.Dari hasil wawancara yang dilakukan peneliti terhadap empat guru yang berbeda, dapat disimpulkan bahwa pengembangan sumber daya manusia atau pelatihan sangat diperlukan. Walaupun tenaga pendidik atau guru menjadi pengajar bagi murid - muridnya, akan tetapi kemampuan yang dimiliki guru juga harus terus berkembang dan proses belajar pada guru terus dilakukan melaui pelatihan. Maka, kesimpulan pengembangan sumber daya manusia dan program pelatihan di SDN Inpres Angkasa cukup baik. Akan tetapi berdasarkan hasil observasi dalam pelaksanaannya, pelatihan yang diberikan kepada tenaga pendidik belum terlaksana dengan baik. Dikarenakan kendala kendala yang tidak diinginkan seperti kesibukan guru - guru dalam menyiapkan program belajar mengajar maupun ujian sekolah. Akibatnya dalam peningkatan mutu pendidikan belum sesuai dengan perencanaan yang telah tersusun di dalam program dan perlu adanya tinjauan

\section{SIMPULAN}

Pendapat setiap sumber daya manusia atau tenaga pendidik pada Sekolah Dasar tersebut sangat mendukung adanya program pelatihan dalam meningkatkan mutu pendidikan. Dengan pelatihan, sumber daya manusia atau tenaga pendidik dapat mengembangkan segala aspek kemampuan sesuai dengan tugas pokok dan fungsi/Tupoksinya masing - masing. Kesimpulannya bahwa pengembangan sumber daya manusia atau tenaga pendidik di SDN Inpres Angkasa sudah berjalan baik. Akan tetapi dalam pelaksanaan program pelatihannya belum maksimal, dan hasil yang didapat dalam pengembangan sumber daya manusia atau tenaga pendidik di SDN Inpres Angkasa perlu adanya tindakan penyempurnaan pada aspek pelaksanaan. Sehingga program pelatihan yang telah direncanakan berjalan sesuai dengan harapan yang diinginkan. Walaupun sesuatu yang sempurna itu tidak mungkin, tetapi dalam zaman modern seperti ini lembaga atau instansi pendidikan dituntut agar terus berusaha mempertahankan sekaligus meningkatkan apa yang menjadi tujuannya. Contohnya seperti pengembangan sumber daya manusia atau tenaga pendidik dalam meningkatkan mutu pendidikan ini. Berdasarkan kesimpulan di atas, maka peneliti mencoba untuk memberikan 
50| Jurnal Office, Vol.3, No.1, 2017

saran yang mungkin bermanfaat bagi pihak sekolah yaitu kepala sekolah, tenaga pendidik/ guru dan seluruh staf SDN Inpres Angkasa Biak. Dalam upaya pengembangan sumber daya manusia atau tenaga pendidik, perlu adanya program pelatihan yang tersusun dan terlaksana dengan baik sesuai perencanaan. Dan semoga pengembangan sumber daya manusia atau tenaga pendidik ini dilakukan secara berkelanjutan atau terus menerus agar dalam meningkatkan mutu pendidikan mendapatkan hasil yang optimal. Diharapkan bagi seluruh tenaga pendidik atau guru di SDN Inpres Angkasa agar terus meningkatkan seluruh keterampilan mengajar dan kemampuan dalam melaksanakan pekerjaan sesuai tugas pokok dan fungsi (Tupoksi).

\section{DAFTAR PUSTAKA}

Arbi, S. Z., \& Syahrun, S. (1993). Dasar-dasar kependidikan. Dirjen Dikti,(1991/1992: 74).

Ariani, D. (2013). Peningkatan Motivasi Dan Keterampilan Berhitung Melalui Penggunaan Media Batang Napier Dalam Pembelajaran Matematika Kelas IV SDN 03 Rejosari Kudus. Universitas Muhammadiyah Surakarta.

Departemen Pendidikan Nasional. (2008). Panduan Pengembangan Bahan Ajar. Jakarta: Depdiknas.

Latham, G. P., Wexley, K. N., \& Pursell, E. D. (1975). Training managers to minimize rating errors in the observation of behavior. Journal of Applied Psychology, 60(5), 550.

Nurgiyantoro, B. (2010). Penilaian Pembelajaran Sastra Berbasis Kompetensi. Yogyakarta: BPFE.

Oktama, R. Z. (2013). Pengaruh Kondisi Sosial Ekonomi Terhadap Tingkat Pendidikan Anak Keluarga Nelayan Di Kelurahan Sugihwaras Kecamatan Pemalang Kabupaten Pemalang Tahun 2013. Universitas Negeri Semarang.

Puspitarini, D., \& Kusumawati, F. (2011). Faktor-Faktor Yang Mempengaruhi Minat Mahasiswa Mengikuti Pendidikan Profesi Akuntansi (PPAk). InFestasi, 7(1), 46-63.

Suhartono, S. (2008). Wawasan pendidikan: Sebuah Pengantar Pendidikan. Yogyakarta: ArRuzz Media.

Suparno, P. (2001). Teori Perkembangan Kognitif Jean Piaget. Kanisius.

Syamsuddin Makmun, A. (2003). Psikologi Pendidikan. Bandung: PT Rosda. Karya Remaja.

Undang-undang Republik Indonesia nomor 20 tahun 2003 tentang sistem pendidikan nasional. Undang-undang Republik Indonesia nomor 20 tahun 2003 tentang sistem pendidikan nasional. PRESIDEN REPUBLIK INDONESIA.

Widoyoko, E. P. (2009). Evaluasi program pembelajaran. Yogyakarta: Pustaka Pelajar.

Yudhoyono, S. B. (2007). Mari, Kita Sukseskan Program Pro-Rakyat. Pidato Awal Tahun Presiden Susilo Bambang Yudhoyono. Jakarta, 31. 